\title{
Technology managers do their bit for world health
}

SIR — Your Editorial “Wanted: social entrepreneurs" (Nature 434, 941; 2005) made several disparaging remarks about the academic technology-transfer profession to which I wish to respond.

You stated: "University technology offices tend to patent aggressively, look no further than generating income, and often fail to include provisions beneficial to tackling orphan diseases in their licensing deals with companies."

First, the top priority of any office of technology transfer is to get a qualified company to make a serious commitment to develop each technology. Of course we negotiate hard to ensure that if the project is a success we are fairly compensated, but the most contentious part of most negotiations is generally not the financial terms but the due-diligence terms - the resource commitment that the company makes to develop the technology.

As Mary Sue Coleman, president of the University of Michigan, recently said in remarks to the 2005 Annual Meeting of the Association of University Technology Managers (AUTM): “Our interest in commercializing technology, in nurturing start-up companies and facilitating patents and licence agreements is not about the promise of future revenues. Of course, revenue generation serves as an incentive. But first and foremost, tech transfer must serve our core mission: sharing ideas and innovations in the service of society's well-being."

Second, I disagree with your assertion that licensing offices are not sensitive to global health issues. In the AUTM 2003 Annual Survey, one of the transactions showcased was a new treatment for Chagas' disease discovered by Washington and Yale universities and licensed by them to the Institute for OneWorld Health, the company that was the focus of your Editorial.

Third, the contact you advocate with the Centre for the Management of Intellectual Property in Health Research and
Development (MIHR) is already under way. For several years there has been a positive dialogue between AUTM and MIHR, largely driven by individuals who belong to both organizations. The focus of the 2006 Annual Meeting of AUTM is improving society, and the plenary session will focus on global health and the elimination of intellectualproperty barriers to bringing advances in neglected diseases to the developing world.

The biggest challenge will be to get the pharmaceutical and biotechnology industries - whose involvement in translating academic discoveries into safe and effective treatments is critical - to accept our proposals. But at least universities can provide leadership and start the discussion. Ashley J.Stevens Office of Technology Transfer, Bostan University, Boston, Massachusetts, and Association of University Technology Managers, Northbrook, Illinois 60062, USA

\section{Ampicillin threat leads to wider transgene concern}

SIR - We are concerned by the suggestion, in your Editorial "Don't rely on Uncle Sam" (Nature 434, 807; 2005), that the US Food and Drug Administration does not consider the presence of the ampicillin-resistance gene in Syngenta's unapproved variety of genetically modified $\mathrm{Bt} 10$ maize to represent a safety problem.

This is not the view of the UK government's scientific advisers (the DEFRA Antimicrobial Resistance Coordination Group), who state that some important veterinary pathogens remain susceptible to ampicillin (K. L. Goodyear et al.

J. Antimicrob. Chemother. 54, 959; 2004). They state that there is "extremely low or no detected resistance in certain bacterial species", so that "any occasional transfer of resistance genes to these organisms would be a very significant event". If, as a result of such horizontal gene transfer, it became necessary to use more modern antimicrobials to treat animal disease, they write, "then there could be significant consequences for the consumer through the food chain".

The risk of horizontal gene transfer from genetically modified organisms (GMOs) is not a theoretical one. One study found that, after $B t$ genes in plasmid form were incubated in the saliva in a sheep's mouth for a few minutes, they could still transform Escherichia coli bacteria so that they developed antibiotic resistance (P. S. Duggan et al. Br. J. Nutr. 89, 159-166; 2003).
In addition, it is worth noting that the ampicillin-resistance gene in Bt10 maize and other genetically modified crops is a remnant of the bacterial plasmid inserted into these varieties, and would therefore function very efficiently if taken up by bacteria as a result of horizontal gene transfer.

Once the Bt 10 maize incident has been dealt with, we feel there should be a review of the general question of horizontal gene transfer from GMOs. There is no reason to believe that any health implications are confined to antibiotic-resistance marker genes; they could, for example, equally apply to the inserted $B t$ toxin genes present in all genetically modified Bt crops. However, the transfer of antibiotic resistance is the only such risk currently being addressed by the authorities that regulate GMOs.

We consider that the case-by-case approval approach used by the authorities does not adequately address such problems, which are common to all GMOs.

Gundula Azeez

Soil Association, 40-56 Victoria Street, Bristol BS1 6BY, UK

\section{Activists should accept mainstream view of GM}

SIR - It is gratifying to read, on your Correspondence page, that environmental campaigners are urging the public to accept the view of a consensus of climatologists, glaciologists and atmospheric physicists that "anthropogenic dimate change is a reality"

\section{"An overwhelming majority of plant geneticists, biochemists and molecular biologists have endorsed the use and safety of genetically modified crops."}

( ${ }^{\circ}$ Time to speak up for climate-change science $^{n}$ Nature 434, 559; 2005). Having accepted the expertise of scientists on this issue, perhaps Greenpeace and Friends of the Earth should reconsider their opposition to genetically modified (GM) crops, as an overwhelming majority of plant geneticists, biochemists and molecular biologists have endorsed the use and safety of these crops. This would allow the economic, environmental and humanitarian benefits of this technology to be fully realized.

As president of a biotechnology company and emeritus professor of biology at Queen's University, Ontario, I agree with the environmentalists that scientists should make their science fully accessible to the general public. If this had been done, all the problems of misinformation and concern about GM use and safety would have been avoided. David T. Dennis

President and chief executive, Performance Plants, BioScience Complex, 116 Barrie Street, Kingston, OntarioK7L 3N6, Canada

Contributions to Correspondence may be submitted tocorres@nature.com.They should be no longer than $\mathbf{5 0 0}$ words, and ideally shorter. Published contributions are edited. 